\title{
A Review of Water Storage for Socio-Economic Development in South Africa
}

\author{
Emmanuel Mwendera, Yonwaba Atyosi \\ Agricultural Research Council, Institute for Soil, Climate and Water, Arcadia, South Africa \\ Email: mwenderae@arc.agric.za, atyosiy@arc.agric.za
}

How to cite this paper: Mwendera, E. and Atyosi, Y. (2018) A Review of Water Storage for Socio-Economic Development in South Africa. Journal of Water Resource and Protection, 10, 266-286. https://doi.org/10.4236/jwarp.2018.103016

Received: December 21, 2017

Accepted: March 13, 2018

Published: March 16, 2018

Copyright $\odot 2018$ by authors and Scientific Research Publishing Inc. This work is licensed under the Creative Commons Attribution International License (CC BY 4.0).

http://creativecommons.org/licenses/by/4.0/

(c) (i) Open Access

\begin{abstract}
South Africa's water resources are limited and unevenly distributed. To overcome the uneven spread of water resources and to manage floods and drought, more than two thirds of the country's mean annual rainfall is currently stored in dams. The paper reviews the current water storage capacity of the country at national and provincial levels. Data from a list of registered dams in the country were used to analyse the water storage capacity of the country. Water storage capacity is highest in Free State Province and lowest in Gauteng Province. The results also show that, while it is clear that the country has invested a lot in developing water storage infrastructure, there is potential for the development of additional infrastructure. However, since most of the major rivers are transboundary, the country needs to develop additional storage with full consideration of its ecological requirements and international obligations.
\end{abstract}

\section{Keywords}

Water Storage, Water Infrastructure, Dams, Water Use, Irrigation

\section{Introduction}

South Africa is a water scarce country with extreme climate, rainfall fluctuations and unevenly distributed water resources. The country has an annual mean runoff value of $40 \mathrm{~mm}$, one seventh of the global average of $260 \mathrm{~mm}$, and rainfall and river flow are variable, erratic and seasonal [1]. The country is semi-arid with rainfall varying from less than $100 \mathrm{~mm}$ per annum in the west to over 1500 $\mathrm{mm}$ per annum in the east. Average rainfall is $450 \mathrm{~mm}$ per annum, which is well below the world average of $860 \mathrm{~mm}$ per annum. Climate change predictions are for a drier western half of the country and for far more variability, with more extreme events, to the east [2]. The country's water usage comprises $77 \%$ surface 
water, $9 \%$ groundwater, and $14 \%$ re-use of return flows [3]. The country's freshwater resources are largely replenished through rainfall. Factors that affect the availability and distribution of water resources in the region include: extremely variable climatic conditions; population dynamics; water-related environmental issues such as the need to maintain ecosystems; economic development; and political and socio-cultural matters such as food security at national, basin, provincial and local levels.

As a water scarce country, South Africa has, for many years, invested in water storage in order to boost water availability for its socio-economic and environmental needs. However, the questions one can ask are: Is the current storage capacity adequate to meet the country's developmental needs? How is water storage capacity at provincial levels? Does the country have potential for developing additional water storage infrastructure? The paper reviews the country's current water storage capacity with the aim of attempting to answer these key questions.

\section{Water Availability}

\subsection{Surface Water}

The available water yield from the main sources in the 19 Water Management Areas in 2004 as reported by the Department of Water Affairs and Forestry [4] is presented in Table 1. The table shows the relevant contributions of different components (surface water, groundwater and return flows) to the available yield in each of the water management areas. The available yield for surface water in 2004 was determined to be in the order of 10,240 million cubic metres per annum $\left(\mathrm{Mm}^{3} / \mathrm{a}\right)$, which was $77.4 \%$ of the country's total yield. In South Africa, substantial volumes of water are returned to streams after use, and are then available for re-use, provided that the quality of the return flows satisfies the relevant user requirements. As showed in Table 1, the total usable return flows in 2004 were close to double the yield from groundwater.

Large-scale inter-basin transfers of water between catchments are a further characteristic of the South African water situation. These transfers are necessary to supplement water to metropolitan areas which are located far away from major water courses.The negative yields from surface water in the Middle Vaal, Lower Vaal and Lower Orange water management areas reflect that evaporation and seepage losses exceed the yield contributed by local runoff in these areas.

In South Africa, the growing economy and social development are giving rise to growing demands for water. Water plays a central role in most of these national planning initiatives, such as agricultural development, energy security, tourism and recreation, mining, industry and municipal water supply. The country's growing population and industrial growth exert a lot of pressure on the limited available water resources in the country. Renewable internal freshwater resources per capita (cubic metres) in South Africa was 942.7 in the period 2013-2017, according to FAO AQUASTAT Main Database [5]. This puts the country in the water stressed category as its water availability is below the water stress line of $1000 \mathrm{~m}^{3} /$ inhabitant/yr (Figure 1). 
Table 1. Available water yield in the year 2004 .

\begin{tabular}{|c|c|c|c|c|c|c|c|}
\hline \multirow{3}{*}{\multicolumn{2}{|c|}{ Water Management Area }} & \multicolumn{2}{|c|}{ Natural resource } & \multicolumn{3}{|c|}{ Usable return flow } & \multirow{3}{*}{$\begin{array}{l}\text { Total } \\
\text { local } \\
\text { yield }\end{array}$} \\
\hline & & $\begin{array}{l}\text { Surface } \\
\text { water }\end{array}$ & Ground-water & Irrigation & Urban & $\begin{array}{c}\text { Mining and } \\
\text { bulk } \\
\text { industry }\end{array}$ & \\
\hline & & \multicolumn{5}{|c|}{$\left(\mathrm{Mm}^{3} / \mathrm{a}\right)$} & \\
\hline 1 & Limpopo & 160 & 98 & 8 & 15 & 0 & 281 \\
\hline 2 & Luvuvhu/Letaba & 244 & 43 & 19 & 4 & 0 & 310 \\
\hline 3 & $\begin{array}{c}\text { Crocodile West and } \\
\text { Marico }\end{array}$ & 203 & 146 & 44 & 282 & 41 & 716 \\
\hline 4 & Olifants & 410 & 99 & 44 & 42 & 14 & 609 \\
\hline 5 & Inkomati & 816 & 9 & 53 & 8 & 11 & 897 \\
\hline 6 & Usutu to Mhlathuze & 1019 & 39 & 42 & 9 & 1 & 1110 \\
\hline 7 & Thukela & 666 & 15 & 23 & 24 & 9 & 737 \\
\hline 8 & Upper Vaal & 598 & 32 & 11 & 343 & 146 & 1130 \\
\hline 9 & Middle Vaal & -67 & 54 & 16 & 29 & 18 & 50 \\
\hline 10 & Lower Vaal & -54 & 126 & 52 & 0 & 2 & 126 \\
\hline 11 & Mvoti to Umzimkulu & 433 & 6 & 21 & 57 & 6 & 523 \\
\hline 12 & $\begin{array}{l}\text { Mzimvubu to } \\
\text { Keiskamma }\end{array}$ & 777 & 21 & 17 & 39 & 0 & 854 \\
\hline 13 & Upper Orange & 4311 & 65 & 34 & 37 & 0 & 4447 \\
\hline 14 & Lower Orange & -1083 & 24 & 96 & 1 & 0 & -962 \\
\hline 15 & Fish to Tsitsikamma & 260 & 36 & 103 & 19 & 0 & 418 \\
\hline 16 & Gouritz & 191 & 64 & 8 & 6 & 6 & 275 \\
\hline 17 & Olifants/Doring & 266 & 45 & 22 & 2 & 0 & 335 \\
\hline 18 & Breede & 687 & 109 & 54 & 16 & 0 & 866 \\
\hline 19 & Berg & 403 & 57 & 11 & 37 & 0 & 505 \\
\hline \multirow{2}{*}{\multicolumn{2}{|c|}{ Total South Africa }} & 10,240 & 1088 & 675 & 970 & 254 & 13,227 \\
\hline & & $77.4 \%$ & $8.2 \%$ & $5.1 \%$ & $7.3 \%$ & $2.0 \%$ & $100 \%$ \\
\hline
\end{tabular}

Source: DWAF [4].

\subsection{Groundwater Resources}

Groundwater is the primary source of reliable, safe drinking water supplies in rural areas and for many towns in South Africa; for the irrigation of thousands of hectares of valuable arable land around the country; and for supporting large numbers of livestock and game [6]. Manymines and industries also rely on groundwater for their supplies. The total volume of available, renewable groundwater in South Africa (the Utilisable Groundwater Exploitation Potential, or UGEP) is 10,343 million $\mathrm{m}^{3} / \mathrm{a}$ (or 7500 million $\mathrm{m}^{3} / \mathrm{a}$ under drought conditions) [7]. According to DWA [7], the country uses between 2000 and 4000 million $\mathrm{m}^{3} / \mathrm{a}$ of this groundwater. Therefore there is the potential to considerably increase groundwater supplies in South Africa. In contrast, the assured yield of 


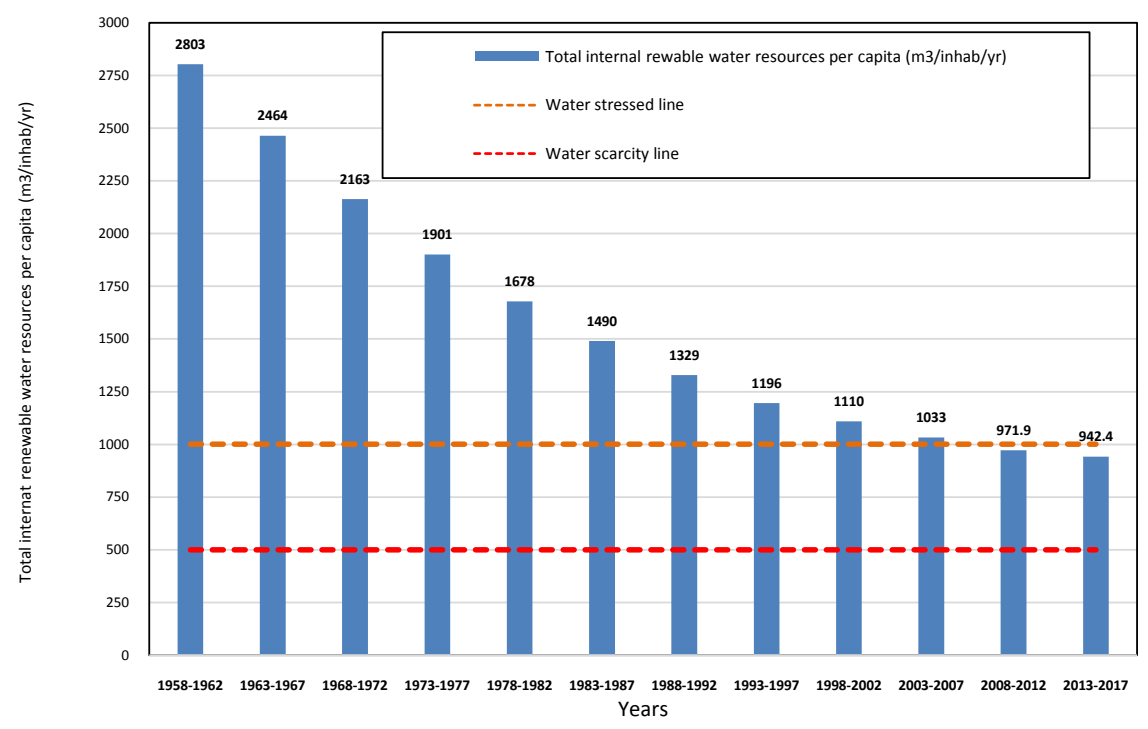

Figure 1. Total renewable water resources in South Africa (Data source: FAO [5]).

South Africa's surface water resources is approximately 12,000 million $\mathrm{m}^{3} / \mathrm{a}$, but more than $80 \%$ of this is already allocated.

In South Africa, groundwater resources are also replenished by artificial recharge, the process whereby surplus surface water is transferred underground to be stored in an aquifer for later abstraction and use. The most common recharge methods used involve injecting water into boreholes (injection wells) and transferring water into spreading basins where it infiltrates the soil subsurface and percolates down into the groundwater [6]. Unlike surface storage, underground water storage is efficient in that the reserves are not vulnerable to evaporation losses and are relatively safe from contamination.

\subsection{Shared Water Systems}

Most fresh water resources in sub-Saharan Africa are located in transboundary watercourse systems and shared river basins. Management and protection of these shared basins is required through a strong commitment to regional collaboration within the Southern African Development Community (SADC). Over $70 \%$ of the region's fresh water resources are shared between two or more Member States [8]. This has been the basis for the development and adoption of a series of regional instruments to support the joint management and development of shared water resources. Since most of the region's water resources occur in the 15 transboundary river basins, sustainable water resource management requires the cooperation of all the riparian states. SADC adopted the Revised Protocol on Shared Water Courses in the Southern African Development Community (SADC Protocol), which established the preconditions for joint management of transboundary water resources [8]. In addition, SADC focuses on developing transboundary water infrastructure for improving the lives of people in the region. 
South Africa, as a signatory to the SADC Revised Protocol on Shared Water Courses; has an obligation to fulfil its commitments through cooperation with its neighbours in the management of international waters in the interest of regional economic integration, peace and security [6]. South Africa shares four major river systems with six neighbouring countries:

- Orange/Senqu system shared with Lesotho, Botswana and Namibia;

- Limpopo system shared with Botswana, Zimbabwe and Mozambique;

- Inkomati system shared with Swaziland and Mozambique; and

- Usuthu/Pongola-Maputo system shared with Mozambique and Swaziland.

This requires South Africa to have long-term cooperative arrangements with its neighbours to avoid water availability being a constraint on future growth. Approximately $60 \%$ of the streamflow in rivers in or on the borders of South Africa is shared through transboundary water systems [6]. South Africa occupies the largest part of each of the transboundary river basins it shares with its neighbours (Table 2).

One of the important shared water systems in South Africa is the Lesotho Highlands Water Project (LHWP) between Lesotho and the Republic of South Africa. The major objective of the LHWP is to assist Lesotho to harness its mountain water resources in order to sell the water to the Gauteng Province, which is the industrial heartland of South Africa [10]. The LHWP was originally envisaged to transfer $70 \mathrm{~m}^{3} / \mathrm{s}$ from the upper portions of the Lesotho Highlands into the Vaal River basin. The scheme was designed in phases, with each phase

Table 2. River systems South Africa shares with neighbouring countries.

\begin{tabular}{cccc}
\hline \multirow{2}{*}{ River system } & Riparian countries & \multicolumn{2}{c}{ Area of basin in the country } \\
\cline { 3 - 4 } Inkomati & South Africa & $\left(\mathrm{km}^{2}\right)$ & $(\%)$ \\
& Mozambique & 14,200 & 62.47 \\
& Swaziland & 3000 & 31.20 \\
& South Africa & 183,500 & 6.33 \\
Limpopo & Mozambique & 87,200 & 21.25 \\
& Botswana & 81,500 & 19.65 \\
& Zimbabwe & 62,600 & 15.08 \\
Maputo & South Africa & 18,500 & 60.31 \\
& Swaziland & 10,600 & 34.71 \\
& Mozambique & 1500 & 4.98 \\
& South Africa & 563,900 & 59.65 \\
Orange & Namibia & 240,200 & 25.40 \\
& Botswana & 121,400 & 12.85 \\
& Lesotho & 19,900 & 2.10 \\
\hline
\end{tabular}

Source: UNEP [9]. 
providing additional transfer capacity to the previous phase with the ultimate transfer of $70 \mathrm{~m}^{3} / \mathrm{s}$ only being achieved on completion of the final phase.

\section{Water Usage in South Africa}

Irrigated agriculture is the largest single user of water in South Africa, at $60 \%$ of total demand (Figure 2). Domestic demand accounts for $29 \%$ in total: $24 \%$ for urban areas and $5 \%$ for rural supply.

In the year 2004, national irrigation water usage was $62 \%$ while irrigation usage in 10 of the 19 Water Management Areas exceeded 70\% (Table 3).

\section{Impact of Climate Change on Water Resources}

Climate change is predicted to impact on the level and variability of Africa's rainfall according to the Intergovernmental Panel on Climate Change (IPCC) [12]. Climate change has the potential to make a significant impact on both the availability of and requirements for water in South Africa. The 2003 South African study on water resource management and climate change [13] indicates that climate change is expected to alter hydrological systems and water resources in southern Africa and reduce the availability of water. Rising temperatures and increasing variability of rainfall will generally affect surface waters, increasing drought in some regions and causing floods in others, as well as influencing groundwater recharge. There is likely to be a general decrease of $5 \%-10 \%$ of present rainfall, with longer dry spells in the interior and north-eastern areas of the country coupled with more frequent and severe flood events [13]. The probable effect is greater evapotranspiration and more stress on arid and marginal zones.

Current climate change prediction scenarios indicate that the net effect of climate change for South Africa will be a reduction of water availability, although impacts will be unevenly distributed, with the eastern coastal areas of the

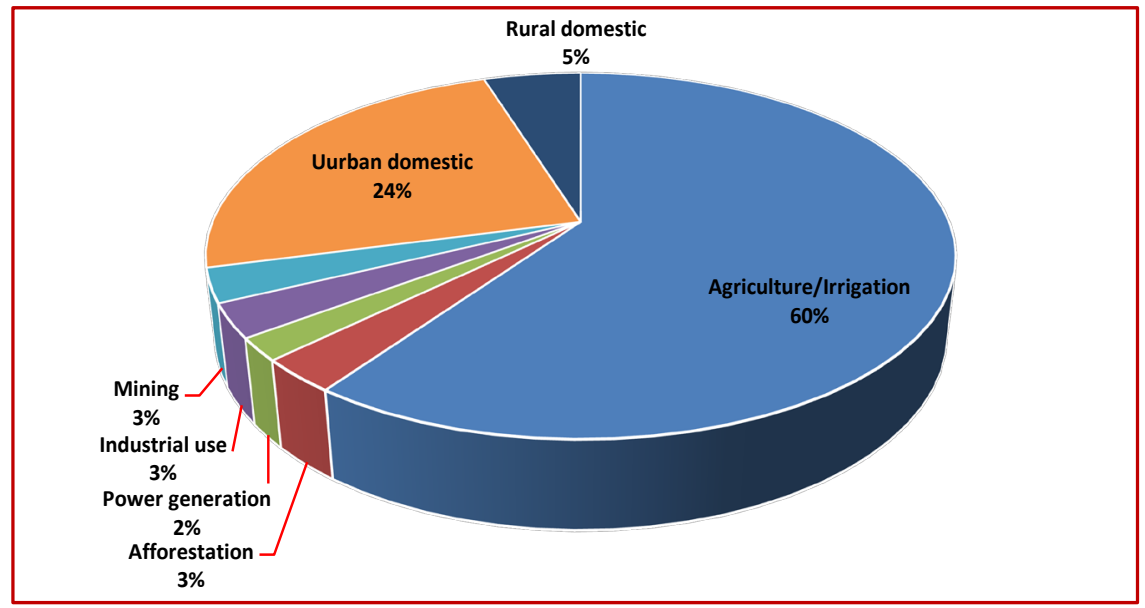

Figure 2. Use of water by major economic sectors in South Africa, 2015 (Source: DWS [11]). 
Table 3. Water requirements for the year 2004.

\begin{tabular}{|c|c|c|c|c|c|c|c|c|}
\hline & \multirow[t]{2}{*}{ Water Management Area } & 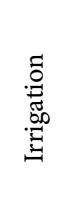 & 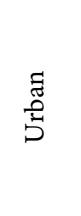 & 莺 & 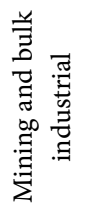 & 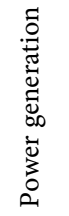 & 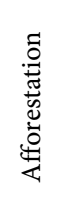 & 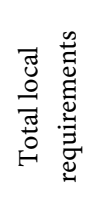 \\
\hline & & \multicolumn{7}{|c|}{$\left(\mathrm{Mm}^{3} / \mathrm{a}\right)$} \\
\hline 1 & Limpopo & 238 & 34 & 28 & 14 & 7 & 1 & 322 \\
\hline 2 & Luvuvhu/Letaba & 248 & 10 & 31 & 1 & 0 & 43 & 333 \\
\hline 3 & Crocodile West and Marico & 445 & 547 & 37 & 127 & 28 & 0 & 1184 \\
\hline 4 & Olifants & 557 & 88 & 44 & 94 & 181 & 3 & 967 \\
\hline 5 & Inkomati & 593 & 63 & 26 & 24 & 0 & 138 & 844 \\
\hline 6 & Usutu to Mhlathuze & 432 & 50 & 40 & 91 & 0 & 104 & 717 \\
\hline 7 & Thukela & 204 & 52 & 31 & 46 & 1 & 0 & 334 \\
\hline 8 & Upper Vaal & 114 & 635 & 43 & 173 & 80 & 0 & 1045 \\
\hline 9 & Middle Vaal & 159 & 93 & 32 & 85 & 0 & 0 & 369 \\
\hline 10 & Lower Vaal & 525 & 68 & 44 & 6 & 0 & 0 & 643 \\
\hline 11 & Mvoti to Umzimkulu & 207 & 408 & 44 & 74 & 0 & 65 & 798 \\
\hline 12 & Mzimvubu to Keiskamma & 190 & 99 & 39 & 0 & 0 & 46 & 374 \\
\hline 13 & Upper Orange & 780 & 126 & 60 & 2 & 0 & 7 & 968 \\
\hline 14 & Lower Orange & 977 & 25 & 17 & 9 & 0 & 0 & 1028 \\
\hline 15 & Fish to Tsitsikamma & 763 & 112 & 16 & 0 & 0 & 7 & 898 \\
\hline 16 & Gouritz & 254 & 52 & 11 & 6 & 0 & 14 & 337 \\
\hline 17 & Olifants/Doring & 356 & 7 & 6 & 3 & 0 & 1 & 373 \\
\hline 18 & Breede & 577 & 39 & 11 & 0 & 0 & 6 & 633 \\
\hline 19 & Berg & 301 & 389 & 14 & 0 & 0 & 0 & 704 \\
\hline \multirow{2}{*}{\multicolumn{2}{|c|}{ Total for South Africa }} & 7920 & 2897 & 574 & 755 & 297 & 428 & 12,871 \\
\hline & & $62 \%$ & $23 \%$ & $4 \%$ & $6 \%$ & $2 \%$ & $3 \%$ & $100 \%$ \\
\hline
\end{tabular}

Source: DWAF [4].

country becoming wetter [6]. In the interior and the western parts of the country, climate change is likely to lead to more intense and prolonged periods of drought with reduced stream flows [14]. In general, climate change will probably lead to weather events that are more intense and variable, such as sudden high volumes of rainfall, leading to flooding [2]. Even small changes in rainfall can lead to disproportionately large changes in water resources. For example, from the study of Mukheibir [15] in the Western Cape it was estimated that an 8\% reduction in rainfall results in a $36 \%$ reduction in groundwater recharge and a $30 \%$ reduction in surface runoff. Surface and groundwater, conjunctively managed, are at the centre of climate adaptation strategies, and improved and expanded water storage capacities create buffers for periods of water shortages [16] [17]. 


\section{Water Storage Infrastructure}

\subsection{Investment in Water Infrastructure}

The lack of storage infrastructure has major negative social and economic impacts, particularly in a drought-prone region where insufficient water is stored to see countries through multiyear droughts [18]. Water storage facilitates the provision of water for domestic and industrial use; irrigation for sustainable agriculture; generation of hydroelectricity; the creation of infrastructure and employment; the improvement of the accessibility of the regions where the big dams are constructed; the promotion of eco-tourism through fishing, canoeing and sight-seeing; and enables the sale of water to thirsty regions and communities within and outside the national boundaries, all of which are a big boost to local and national government revenues and incomes [10].

The Government of South Africa, through Department of Water Sanitation, has continuously increased its investment in the development of bulk raw water and water services infrastructure (Figure 3). As indicated in Figure 3, the expenditure on water infrastructure development is estimated to increase from $\mathrm{R} 6.4 \mathrm{~b}$ in $2012 / 2013$ financial year to R13.8b (which is $80.2 \%$ of the DWS's total budget) in 2018/2019 financial year.

Investment in infrastructure for water resources development and distribution has shown high human and macroeconomic benefits. On the other hand, countries that have limited water storage capability suffer damaging shocks from droughts and floods [20]. Investment in improved water storage to even out water access in and between rainy seasons and support preparedness for flood management is also an imperative part of any poverty reduction strategy. As reported by [21], the role of dams and reservoirs in sustainable development has already been acknowledged in various declarations: World Summit on Sustainable Development (2002), Beijing Declaration on Hydropower and Sustainable

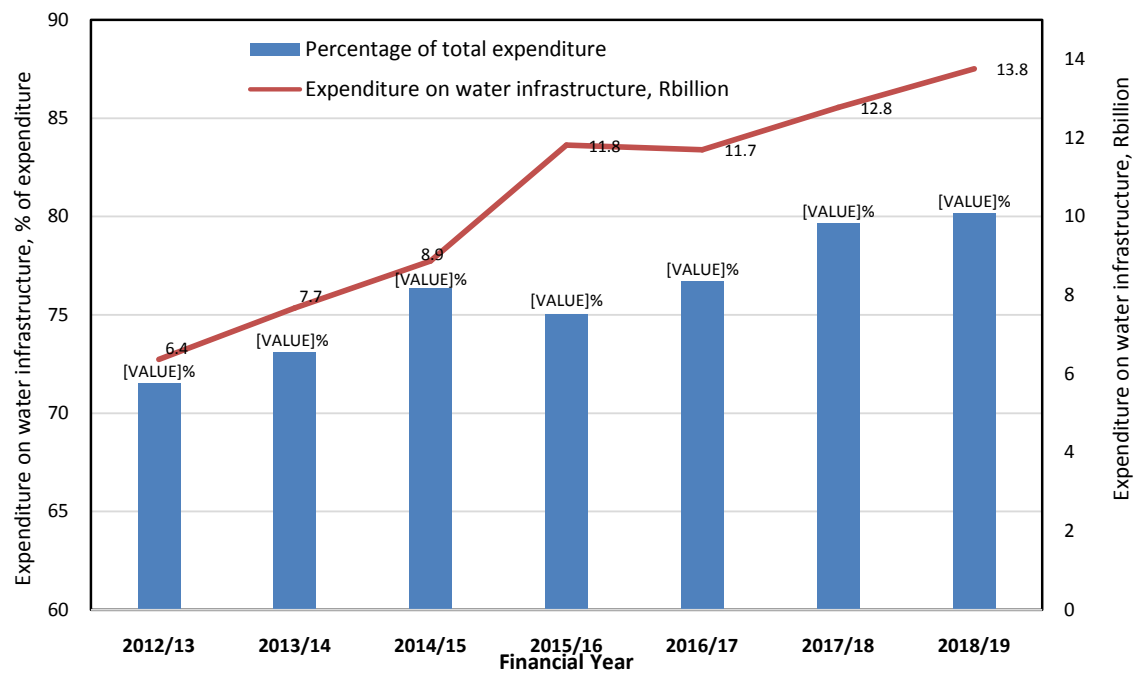

Figure 3. Trend of expenditure on water infrastructure in South Africa (Source: DWS [19]). 
Development (2004), Dams and Hydropower for African Sustainable Development (2008), and the Ministerial Declarations of the Fifth and Sixth World Water Fora (2009/2012). Water is life and water storage infrastructure is an indispensable tool for society. Investment in water storage infrastructure is investment in the green economy [21].

\subsection{Major Dams in South Africa}

In order to overcome the uneven spread of water resources and to manage floods and drought which the country experiences, South African government has invested a lot of money in the construction of dams that currently store more than two thirds of the country's mean annual rainfall [19]. Based on the 2016 database on dams, the country has more than 5000 registered dams spread across all nine provinces, which include those owned by the Department of Water and Sanitation (DWS) and those owned privately. In 2011 the DWS owned approximately 305 dams with a total capacity of 29.2 billion $\mathrm{m}^{3}$, which accounted for $70 \%$ of the total dam capacity in the country [22]. The dams range in storage capacity from a volume of 5300 million $\mathrm{m}^{3}$ of water down to less than 0.001 million $\mathrm{m}^{3}$, and a wall height from $100 \mathrm{~m}$ to $3 \mathrm{~m}$. The largest is Gariep Dam (Figure 4) which has a total storage capacity of approximately $5340 \mathrm{Mm}^{3}$ and a surface area of more than $352 \mathrm{~km}^{2}$ when full. It is a concrete gravity-arch hybrid dam constructed primarily to provide water for irrigation, domestic and industrial uses as well as for power generation.

\section{Water Storage Capacity}

\subsection{Water Storage Capacity at National Level}

Improved water resource management and water storage capacity make the

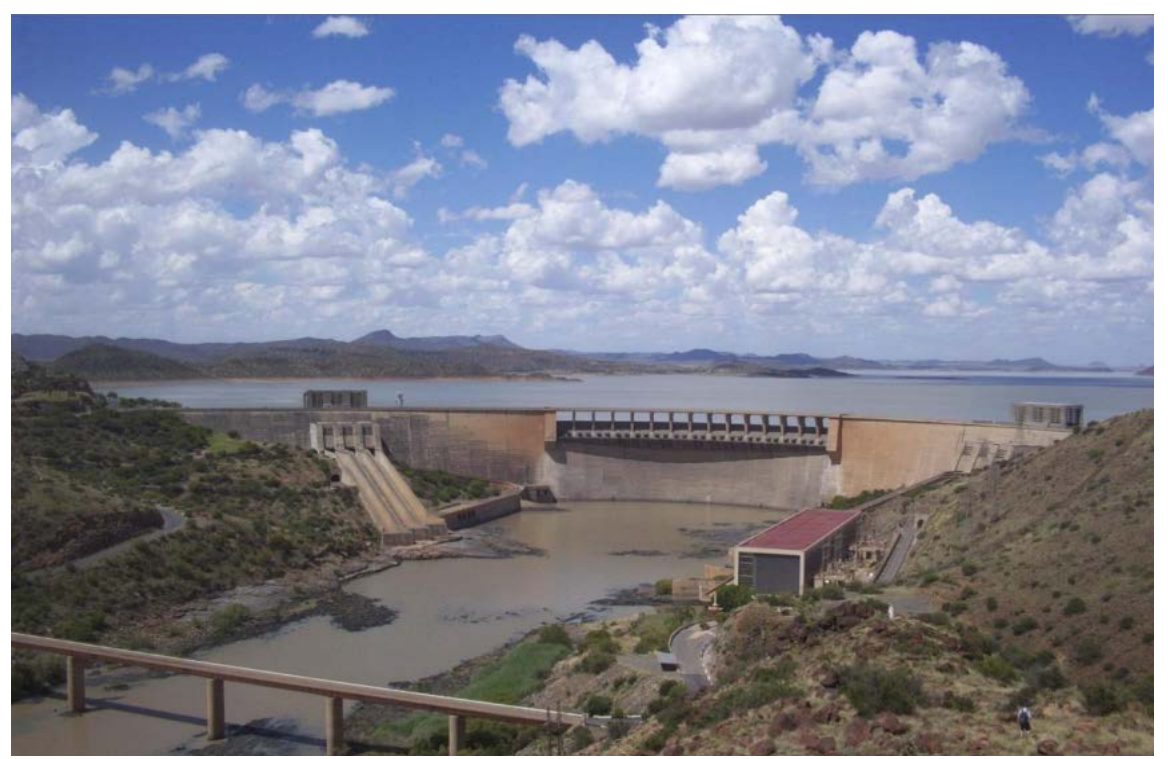

Figure 4. Gariep Dam on the Orange River, Free State Province (Source: Nic Roets at wikitravel.org_http://wikitravel.org/en/Image:Gariep_Dam.jpg). 
economy more resilient to external shocks, such as rainfall variability anddrought, and thus provide a stable and sustainable base for increased food and industrial productivity and production to maintain economic growth and development [23]. South Africa has developed a vast amount of water storage infrastructure, which still needs to be increased in order to improve the water storage capacity (Figure 5).

Apart from investment in water storage infrastructure, the DWS supports a national water harvesting programme (rainwater and fog harvesting), which, at present, has a narrow but important focus on the provision of above- and below-ground water storage tanks for rural households and other institutions such as clinics, schools and hospitals [6]. The harvested water is often used for irrigation of food gardens to improve food sufficiency and for other productive water uses, and for domestic purposes where communities do not have a reliable source of potable water.

\subsection{Water Storage Capacity at Provincial Level}

At provincial level, the Free State has the largest storage capacity, followed by KwaZulu-Natal, while Gauteng has the lowest storage volume (Figure 6). Figure 7 presents the water storage capacities per person in all nine provinces. The results show that the Free State has the highest storage capacity with Gauteng the lowest. Free State Province has 160 times more storage capacity per person than Gauteng Province.

\section{Water Storage for Climate Change Adaptation}

Water storage (in all its forms) has a key role to play for both sustainable development and adaptation to climate change. By providing a buffer, water storage reduces risk and offsets some of the potential negative impacts of climate

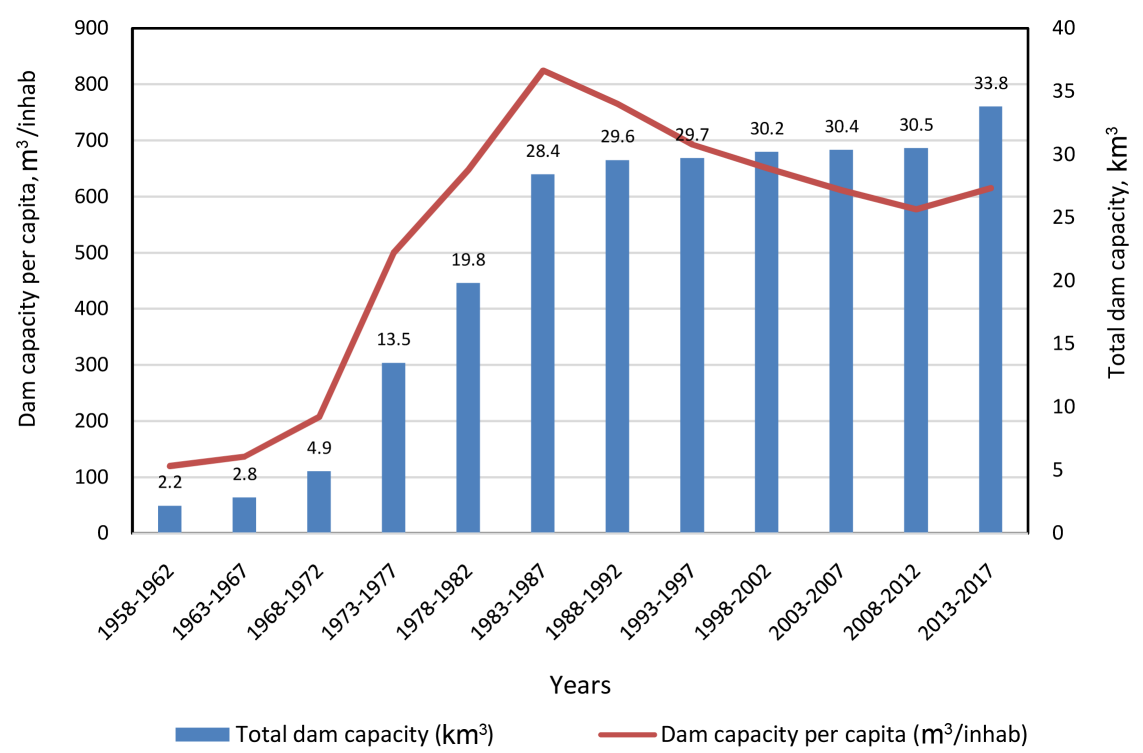

Figure 5. Dam capacity in South Africa (Data source: FAO [5]; DWS [24]). 


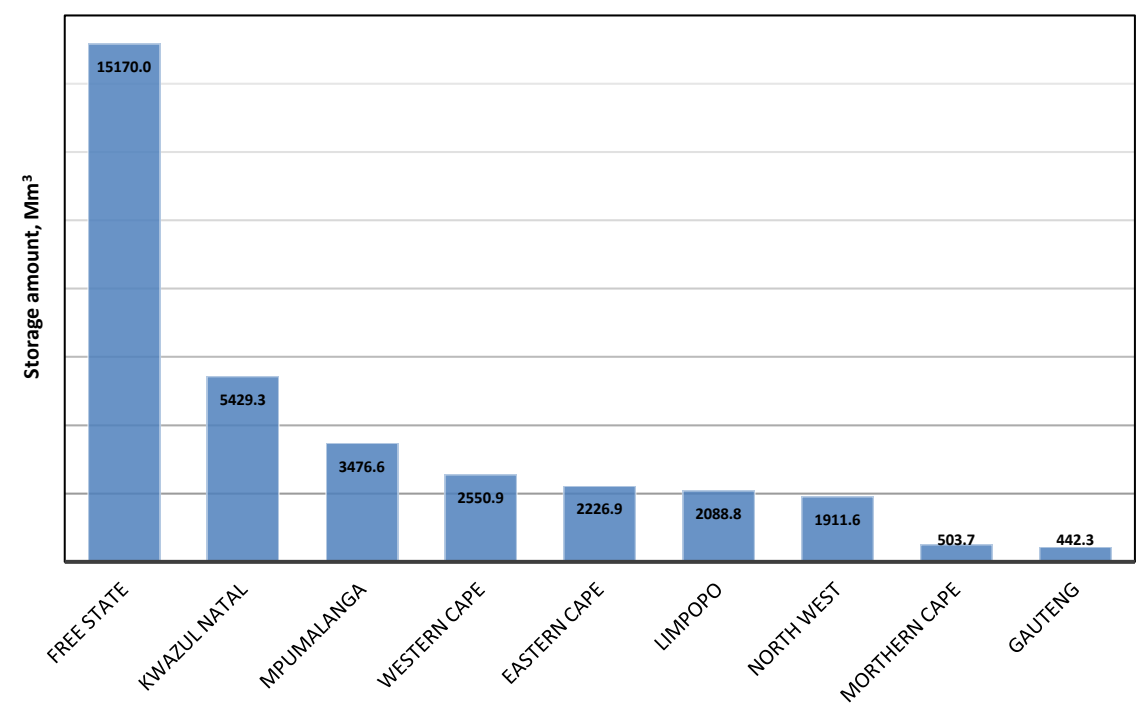

Figure 6. Water storage amount by province in South Africa, 2016 (Data source: DWS, list of registered dams in South Africa in 2016).

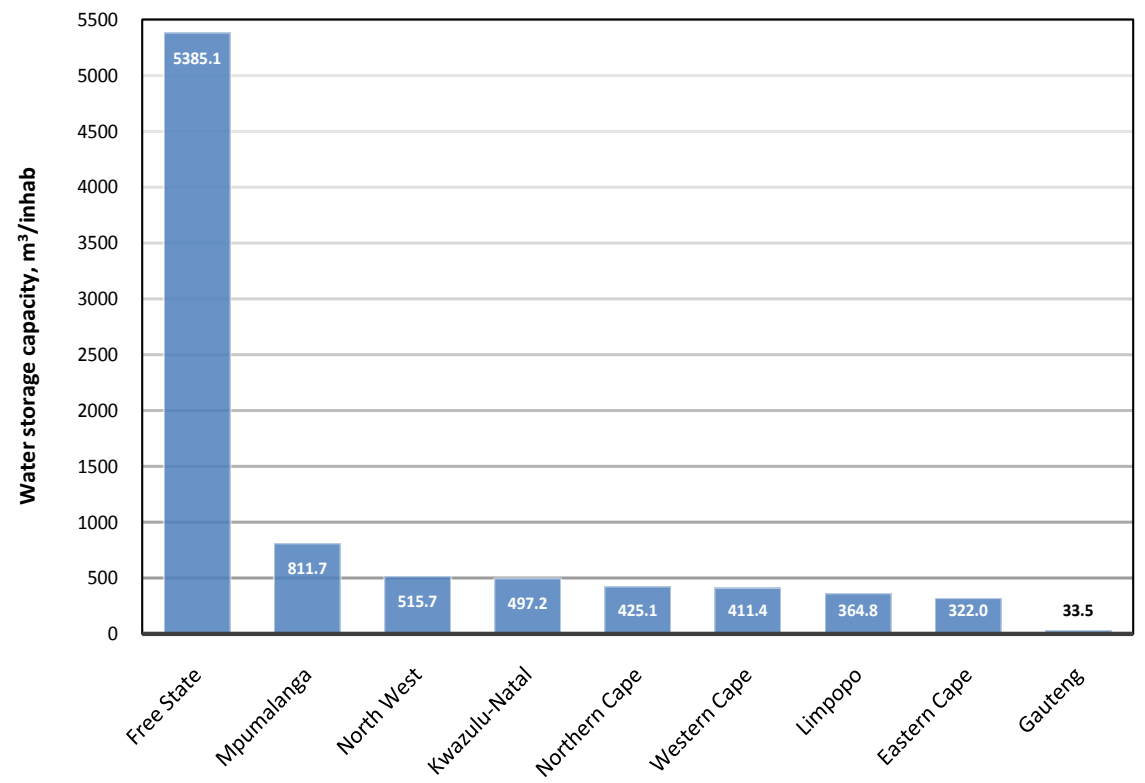

Figure 7. Water storage capacity per person by province in South Africa, 2017 (Data source: DWS, list of registered dams in South Africa in 2016).

change, thereby reducing the vulnerability of people [25]. Water storage can enhance both water security and agricultural productivity (Figure 8).

The South African government has developed a water sector response that spells out climate change adaptation strategies based on risk and vulnerability reduction, in collaboration with sector stakeholders and neighbouring riparian countries, and seeks to share resources, technology and learning to coordinate a regional response [24]. The underlying principles are to build resilience and reduce vulnerability to the water related impacts of climate change. Strategic actions focus on infrastructure development, which includes [24]: 


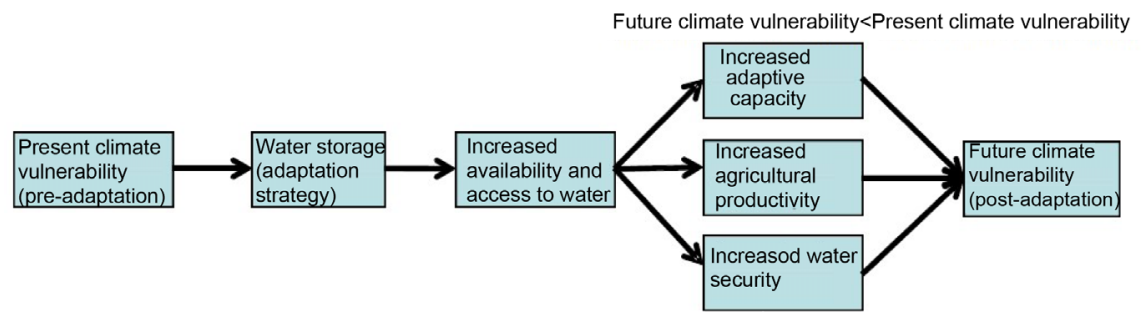

Figure 8. Water storage as an adaptation strategy to reduce climate vulnerability (Source: McCartney and Smakhtin [25]).

- Multi-purpose water storage;

- Water supply and sanitation;

- Groundwater development;

- Alternative water supply sources;

- Flood protection measures;

- Infrastructure safety; and

- Hydro-geo-meteorological monitoring system.

\section{Water Storage for Multiple Uses}

Large intra-year variability and multi-year droughts characterise South Africa's catchment hydrology; therefore, considerable storage capacity is required to ensure reliable water supply during seasonal and multi-year deficient flow periods [2]. The purpose of water storage includes: water supply for household use, industry, livestock and irrigation; hydropower generation; buffering against floodwaters and protection against droughts; artisanal and commercial fisheries and aquaculture; transportation; sites for recessional cropping and grazing; sinks for pollutants, including sewage and inflowing sediments; tourism based on biodiversity, scenery or sporting activities; cultural and religious uses; and sites for biological diversification [26].

A significant challenge in water resource planning is to ensure a smooth integration of the provision of water supplies for domestic use and water for other purposes leading to economic production, particularly in rural areas. Water for domestic supplies in rural areas is used for various household purposes such as cooking, washing, food gardens, stock watering and small businesses. If water is provided mainly for irrigation, it can also be used for domestic purposes, and if water is provided for domestic purposes, it will be used for other purposes too. In South Africa, water is stored for multiple uses, which include: irrigation for food production; fisheries; energy production; industrial water supply; mining; drinking water and sanitation; stock water; flood management and drought mitigation; recreation; pollution control; game watering; and environmental services (Figure 9). At national level, much of water is stored for irrigation, municipal and industrial use, domestic use and hydropower generation.

One of the government's strategies in water infrastructure development is to ensure that water storage infrastructure, particularly major storage dams, is developed for multi-stakeholder use, including social and economic uses, and to 


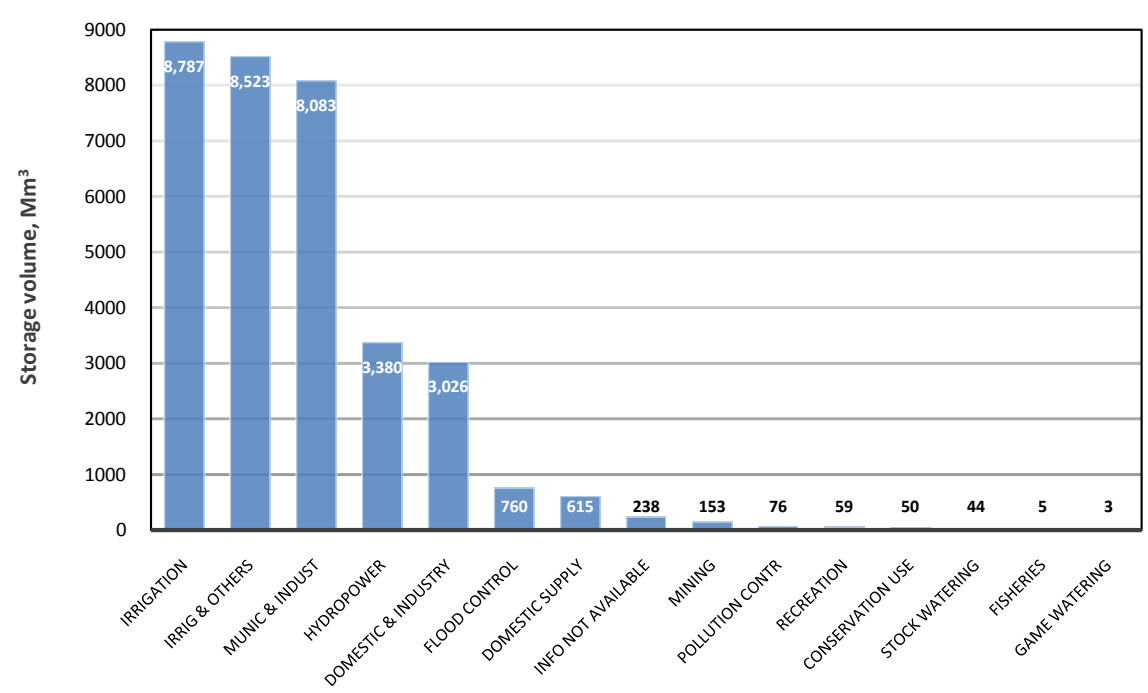

Figure 9. Water storage capacity and main purpose of storage in South Africa (Data source: DWS, list of registered dams in South Africa in 2016).

ensure that poor communities in the vicinity of state-owned infrastructure benefit from it [6].

The main purpose of provincial water storage is irrigation, industrial, municipal and domestic use (Figures 18-20). In the Eastern Cape, water storage is mainly for industrial, irrigation, municipal, and domestic use, as well as flood control (Figure 10). In the Free State, water is stored mainly for irrigation, hydropower generation, municipal, industrial and domestic use (Figure 11). In the Western Cape the main uses are irrigation, municipal, domestic and industrial (Figure 12), but some water storage is for flood control and hydropower generation. The main purpose of water storage in the Northern Cape is irrigation, municipal and domestic use (Figure 13), but there is a substantial amount of storage registered without specifying its purpose.

In Kwa Zulu-Natal, the main purpose of water storage is for irrigation, municipal, industrial and domestic use (Figure 14). In Mpumalanga, storage is mainly for municipal, industrial and irrigation use, followed by mining and domestic use, hydropower generation and pollution control (Figure 15). In Limpopo, flood control, municipal and industrial use, irrigation and domestic use, followed by pollution control and mining are the main reasons for water storage (Figure 16). In North West, irrigation is the main purpose of water storage, followed by municipal and industrial use (Figure 17). Finally, in Gauteng, water storage is mainly for irrigation, municipal and industrial use, as well as flood control, followed by pollution and domestic use (Figure 18).

In some provinces the purpose of water storage also includes stock watering, recreation, fisheries, game and conservation use.

\section{Water Storage by Dam Size}

An assessment of the size of dams in South Africa shows that $82 \%$ of water is 


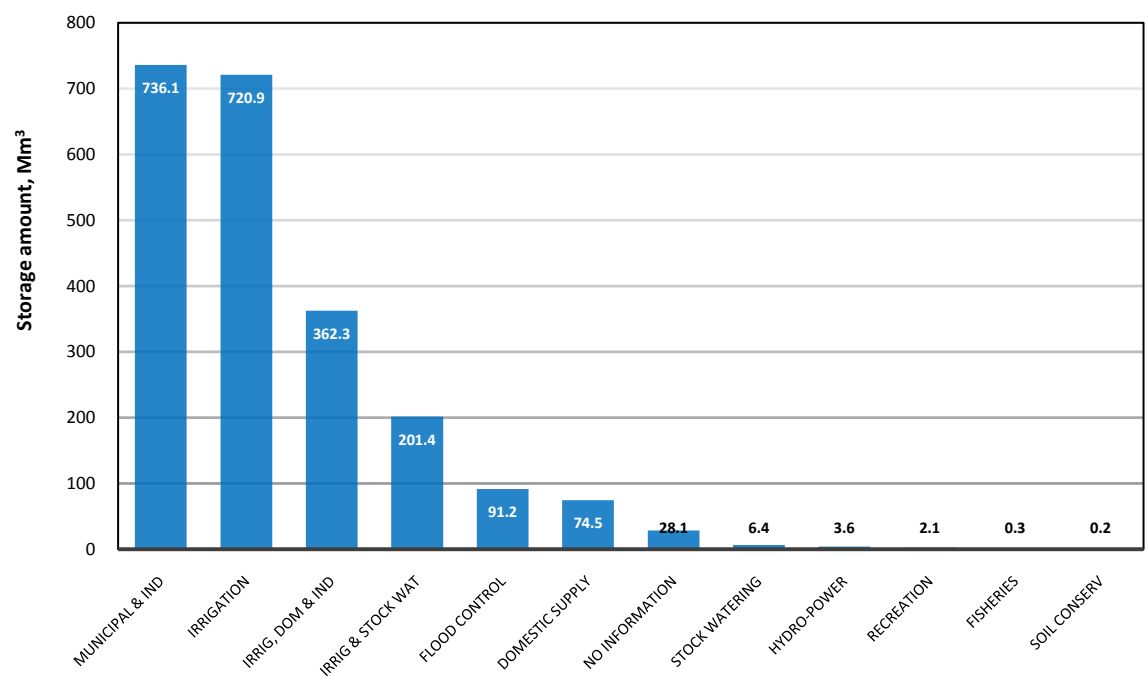

Figure 10. Water storage capacity and main purpose of storage in Eastern Cape Province (Data source: DWS, list of registered dams in South Africa in 2016).

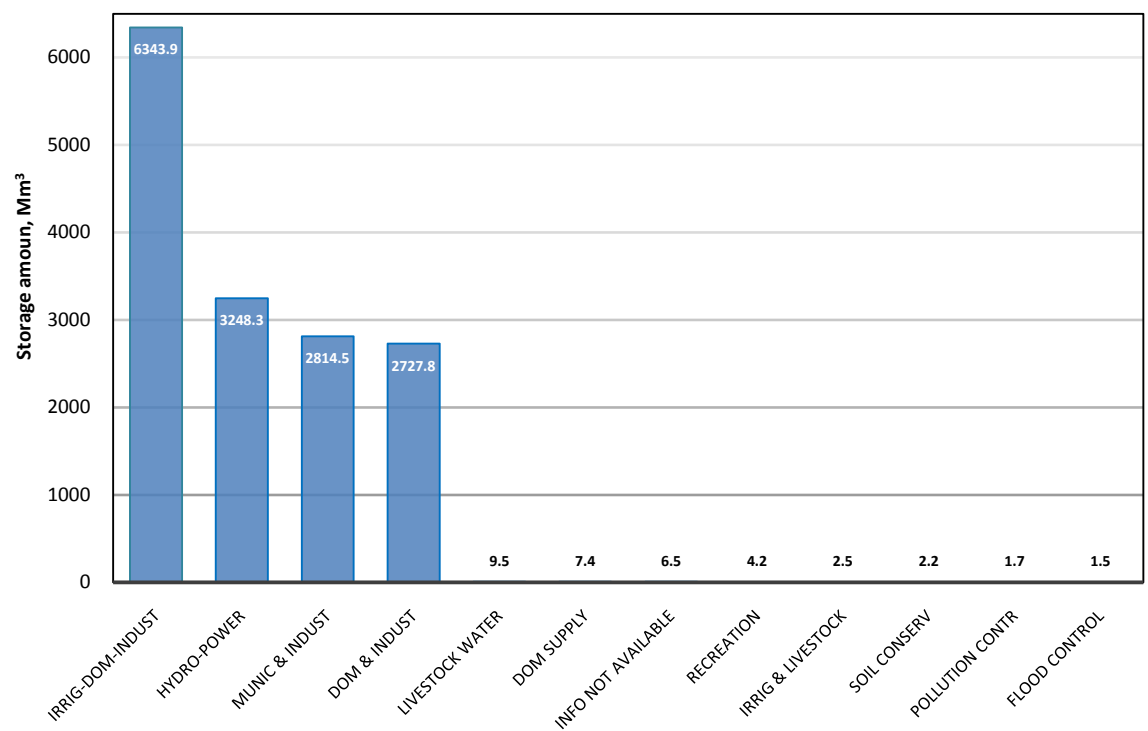

Figure 11. Water storage capacity and main purpose of storage in Free State Province (Data source: DWS, list of registered dams in South Africa in 2016).

stored in dams with a capacity exceeding $100 \mathrm{Mm}^{3}$ (Figure 19). It also shows that $87 \%$ of the water is stored in large dams with wall heights above $25 \mathrm{~m}$ (Figure 20).

\section{Conclusions}

\subsection{Economic Benefits of Water Storage}

Water storage capacity per person is often cited as a proxy to water security and a measure of large- and small-scale water infrastructure development [27]. Well planned and efficiently managed water storage infrastructure is important for the provision of a safe and secure water supply to households, agriculture and 


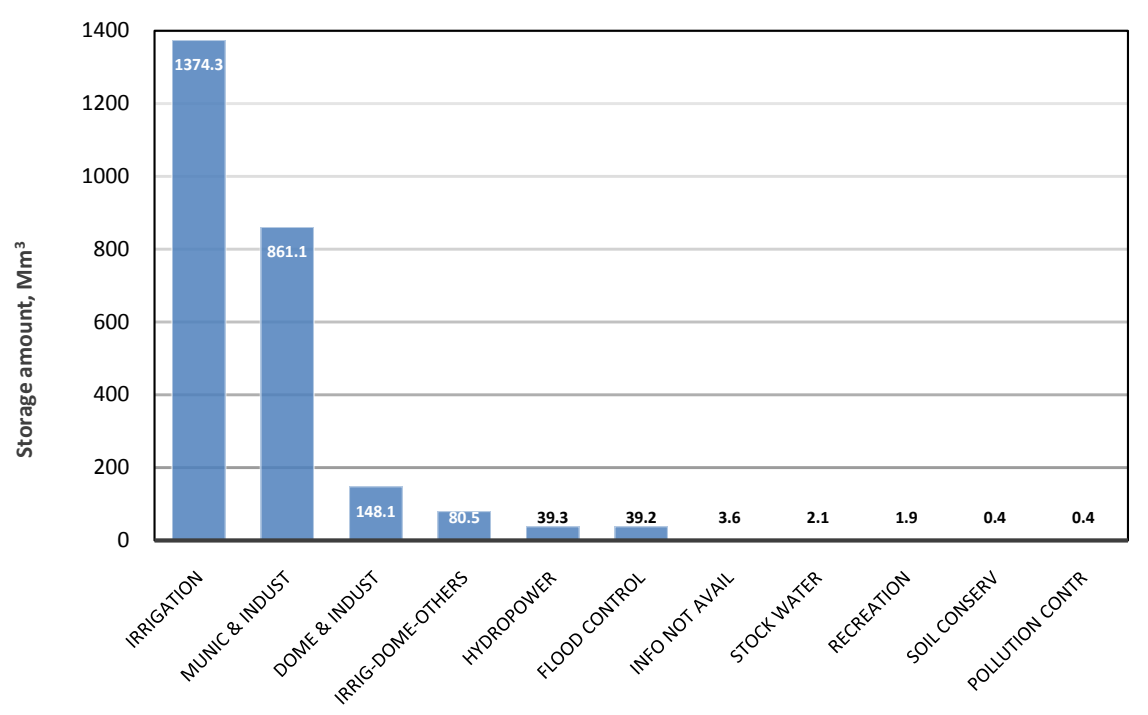

Figure 12. Water storage capacity and main purpose of storage in Western Cape Province (Data source: DWS, list of registered dams in South Africa in 2016).

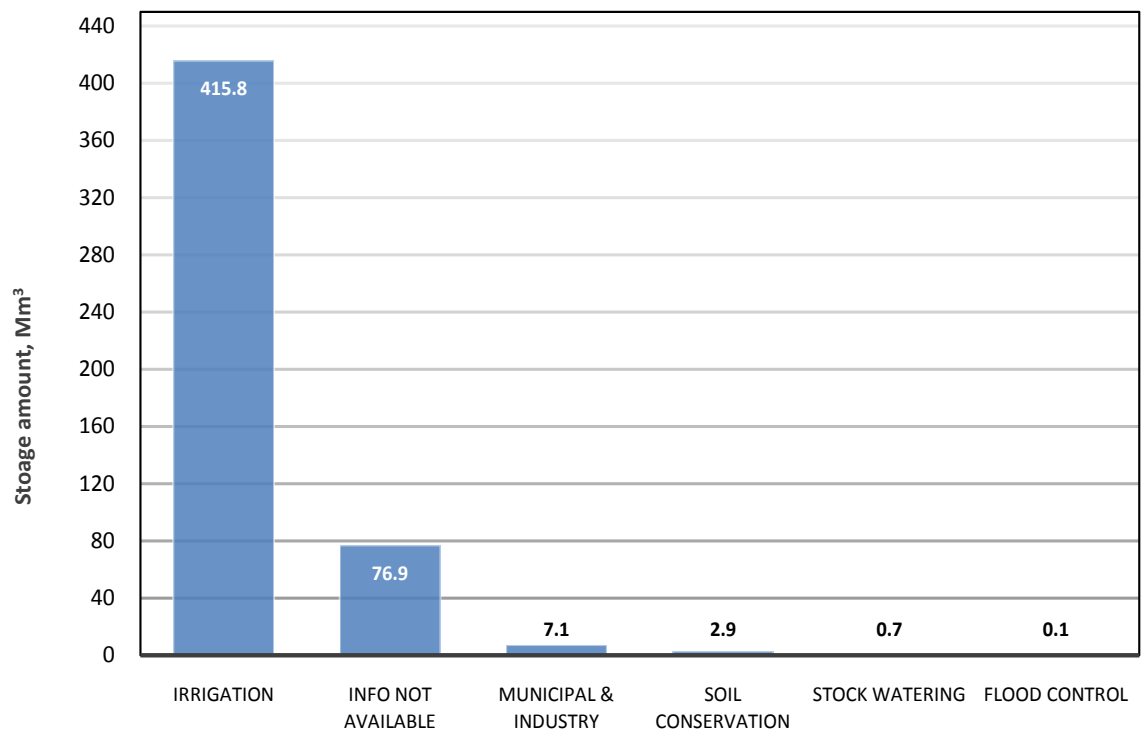

Figure 13. Water storage capacity and main purpose of storage in Northern Cape Province (Data source: DWS, list of registered dams in South Africa in 2016).

industry. Multi-purpose dams can generate direct and indirect economic benefits. For example, investment in water storage infrastructure creates economic opportunities for businesses directly involved in the design, engineering and construction of water infrastructure. Improved water storage capacity and water security are particularly required in climate zones characterised by low rainfall and major rainfall variability, such as South Africa.

One of the purposes of water storage in South Africa is hydropower generation. Hydropower is a renewable source of energy for which there is still substantial development potential. The benefits of renewable electrical energy are 


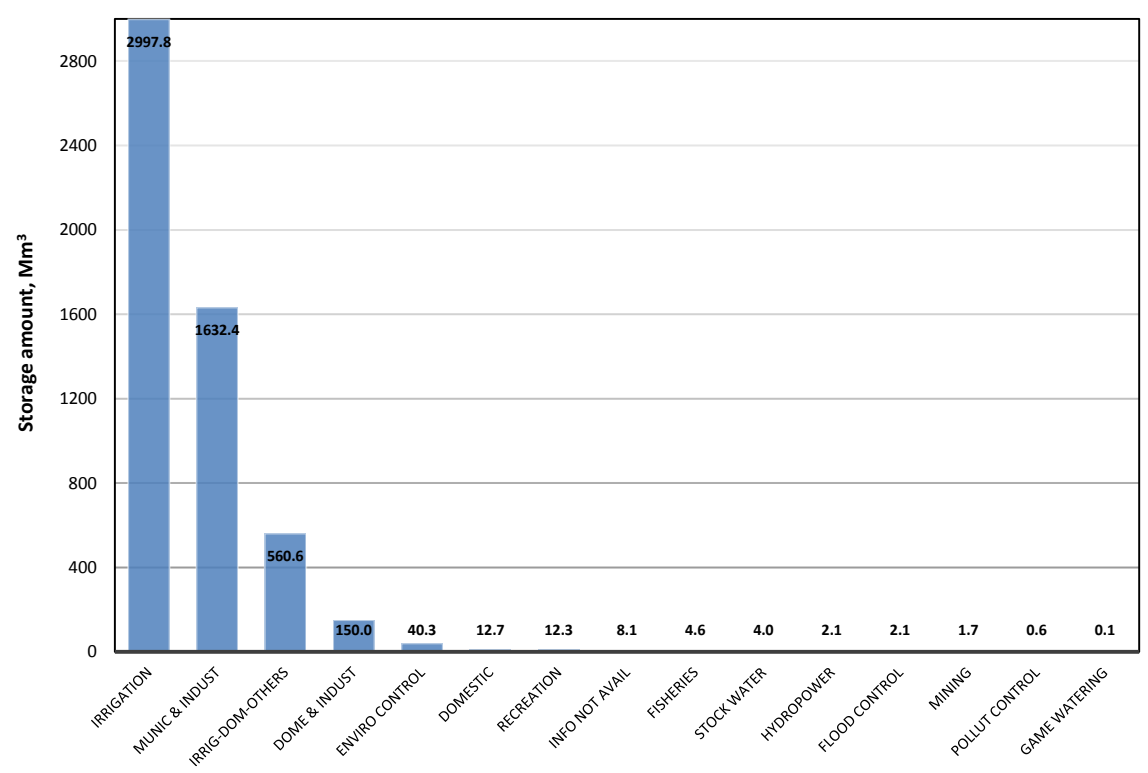

Figure 14. Water storage capacity and main purpose of storage in KwaZulu-Natal Province (Data source: DWS, list of registered dams in South Africa in 2016).

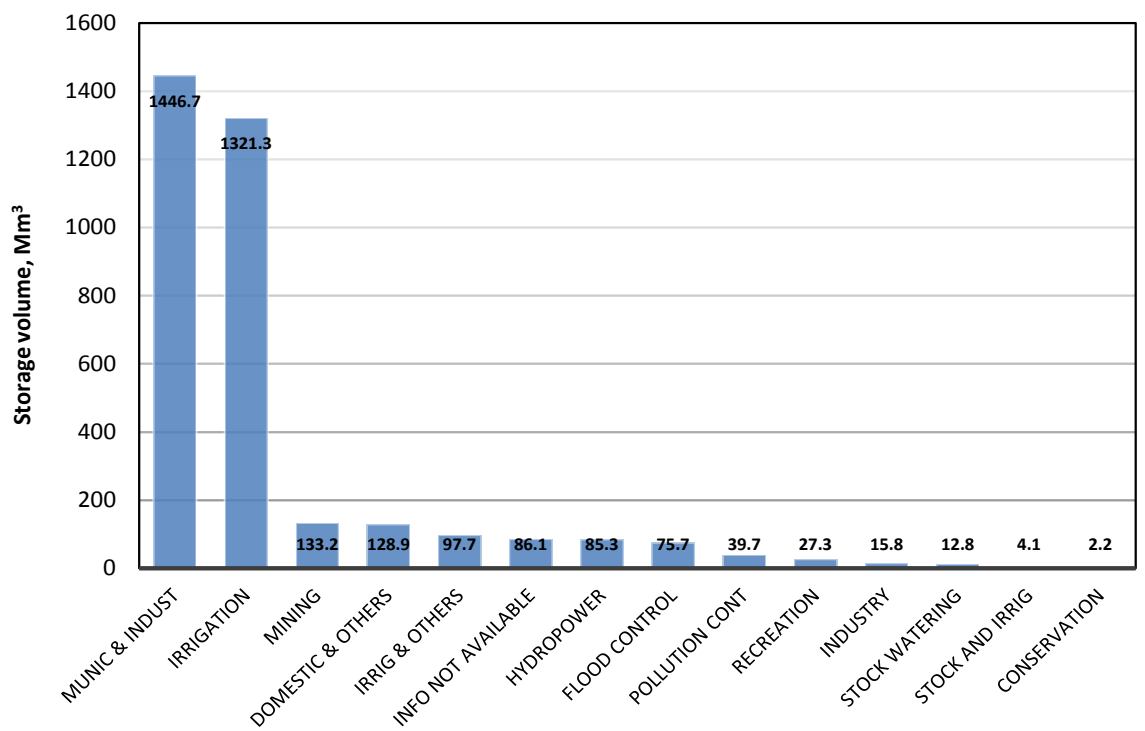

Figure 15. Water storage capacity and main purpose of storage in Mpumalanga Province (Data source: DWS, list of registered dams in South Africa in 2016).

clear not only for the economy but for sustainable development as well. Electricity supply that allows for heating, cooking and illumination is not only a great boon to the activities of daily life, but is also a critical input to agriculture and a host of small-scale production activities that are a significant component of rural and urban economies.

Stored water is essential to all aspects of life. It sustains families and communities. It also supports economic productivity, from semiconductor manufacturing, to agriculture, to hotels and restaurants. Indeed, virtually all sectors of the economy rely on water. 


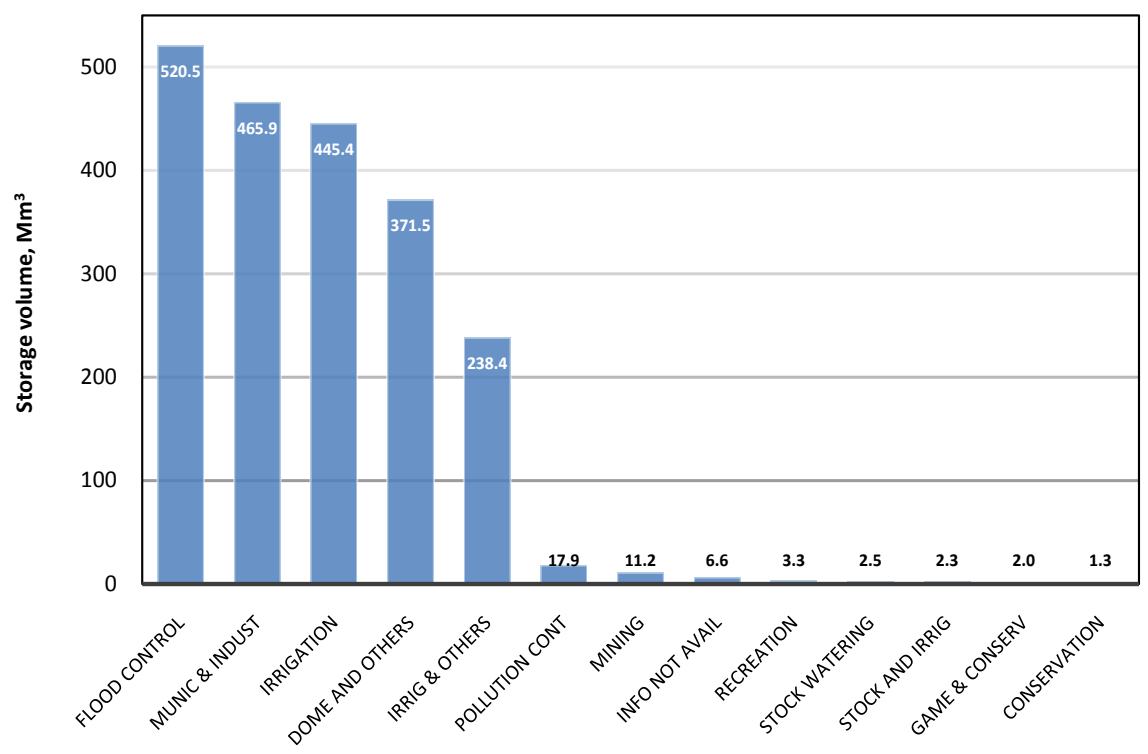

Figure 16. Water storage capacity and main purpose of storage in Limpopo Province (Data source: DWS, list of registered dams in South Africa in 2016).

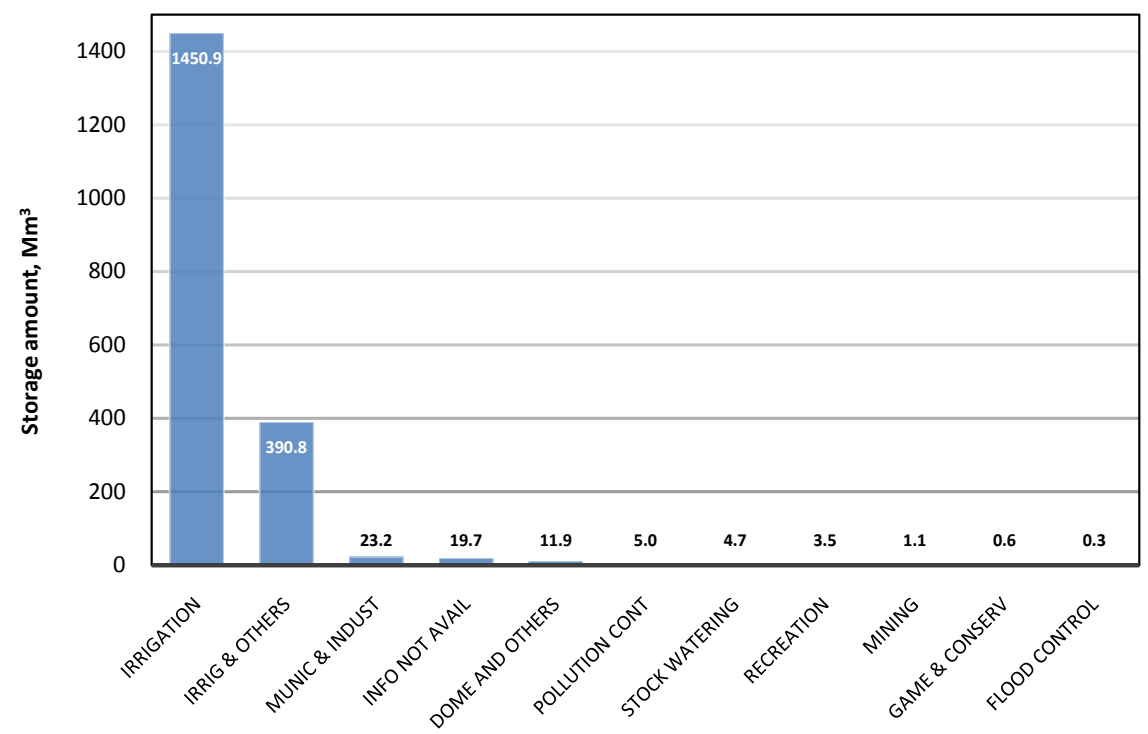

Figure 17. Water storage capacity and main purpose of storage in North West Province (Data source: DWS, list of registered dams in South Africa in 2016).

\subsection{Potential to Develop Additional Storage}

The need for water storage to support socio-economic development in South Africa cannot be overemphasised. Indeed, the National Water Resource Strategy makes provision for investment in water infrastructure to support economic development through a strategy for infrastructure development and management and the National Water Sector Investment Framework [6]. The government uses water infrastructure development, operation and maintenance as a vehicle for job creation and for supporting equitable socio-economic development.

While it is clear that the country has invested a lot in developing water storage 


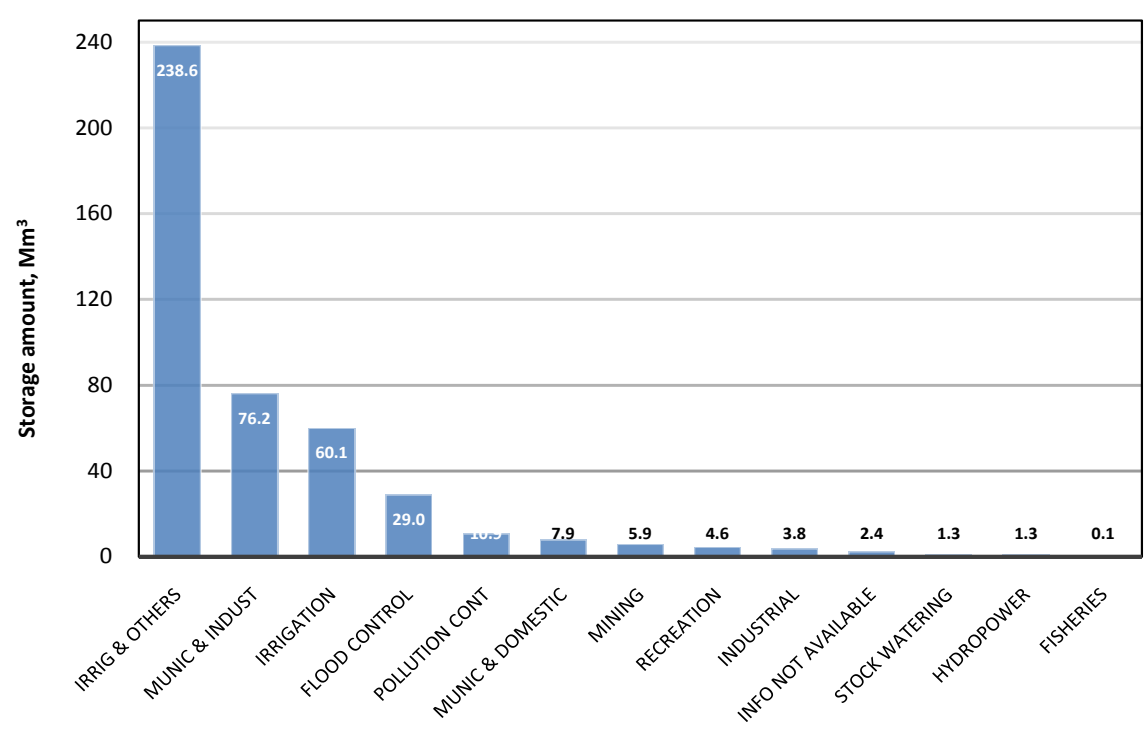

Figure 18. Water storage capacity and main purpose of storage in Gauteng Province (Data source: DWS, list of registered dams in South Africa in 2016).

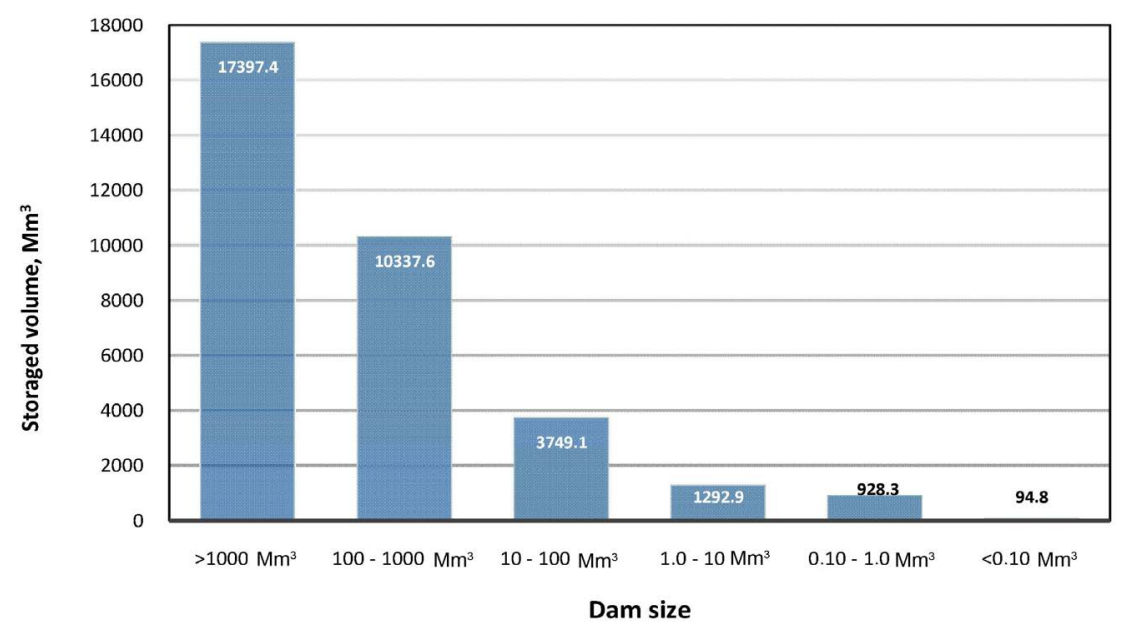

Figure 19. Storage capacity of different dam sizes (by volume) in South Africa (Data source: DWS, list of registered dams in South Africa in 2016).

infrastructure, there is potential for the development of additional infrastructure. For example, there is potentially more water available in the Orange River system which could be harnessed through construction of additional storage infrastructure. In the Crocodile River catchment, the existing dams cannot capture and control all potentially available water, so in theory there is some potential for additional storage. There is also potential for additional storage in the Groot Letaba River catchment area. The DWS [6] has reported that, in the Kwa Zulu-Natal Water Management Area, there are more opportunities for the development of storage infrastructure than in most other WMAs.

It is apparent that South Africa has the potential to increase its water storage capacity. However, since most of the major rivers are transboundary, the country needs to develop additional storage with full consideration of its ecological 


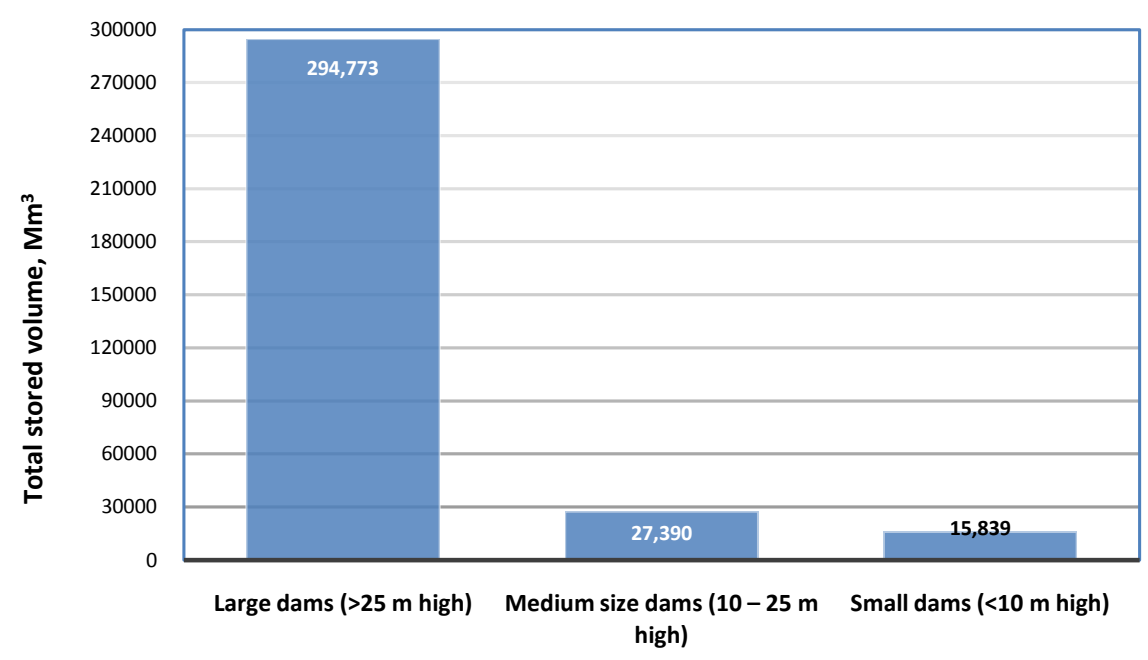

Figure 20. Storage capacity of different dam sizes (by wall height) in South Africa (Data source: DWS, list of registered dams in South Africa in 2016).

requirements and international obligations.

\section{Acknowledgements}

The review work was funded by the Agricultural Research Council. The authors would like to extend thanks to Ms. Rongqiu Cai, Specialist Engineer with the Dam Safety Office, Department of Water and Sanitation, for providing the list of registered dams. The authors also thank Mr. Chris Moseki and Dr. Beason Mwaka of Department of Water and Sanitation (DWS) for their constructive comments to the first draft.

\section{References}

[1] DEA (2011) South Africa's Second National Communication under the United Nations Framework Convention on Climate Change. Department of Environmental Affairs, Republic of South Africa, Pretoria.

[2] DEA (2013) Long-Term Adaptation Scenarios Flagship Research Programme (LTAS) for South Africa. Climate change implications for the water sector in South Africa. Department of Environmental Affairs, Republic of South Africa, Pretoria, 43 p.

[3] DWA (2013) Strategic Review of the Water Sector in South Africa. Department of Water Affairs, Republic of South Africa, Pretoria.

[4] DWAF (2004) National Water Resources Strategy. Department of Water Affairs and Forestry, Republic of South Africa, Pretoria.

[5] FAO (2016) AQUASTAT Main Database, Food and Agriculture Organization of the United Nations (FAO).

http://www.fao.org/nr/water/aquastat/data/query/index.html?lang=en

[6] DWA (2013) National Water Resource Strategy. 2nd Edition, Department of Water Affairs, Republic of South Africa, Pretoria.

[7] DWA (2010) Groundwater Strategy. Department of Water Affairs, Republic of South Africa, Pretoria.

[8] SADC (2011) Regional Strategic Action Plan on Integrated Water Resources Development and Management (2011-2015) RSAP III, Gaborone, Botswana. 
[9] UNEP (2002) Atlas of International Freshwater Agreements. United Nations Environment Programme, Nairobi.

[10] Mashinini, V. (2010) The Lesotho Highlands Water Project and Sustainable Livelihoods. Policy Implications for SADC. AISA Policy Brief Number 22-June 2010. Africa Institute of South Africa, Pretoria.

[11] DWS (2015) National Water Resource Strategy 2. Presentation at workshop on Implementation Adopting a Sector Specific Implementation Strategy to Water Management in South Africa. Department of Water and Sanitation, Pretoria.

[12] IPCC (Intergovernmental Panel on Climate Change) (2007) Climate Change (2007): Synthesis Report. Contribution of Working Groups I, II and III to the Fourth Assessment Report of the Intergovernmental Panel on Climate Change [Core Writing Team, Pachauri, R.K and Reisinger, A. (Eds.)]. IPCC, Geneva, 104 p.

[13] Mukheiber, P. and Sparks, D. (2003) Water Resource Management and Climate Change in South Africa: Visions, Driving Factors and Sustainable Development Indicators. Report for Phase I of the Sustainable Development and Climate Change project. Energy and Development Research Centre, University of Cape Town, Cape Town.

[14] Schulze, R.E. (2011) Summary of Results and Key Findings from the 2011 Study on Climate Change and the Water Related Sector in South Africa. In: Schulze, R.E., Ed., A 2011 Perspective on Climate Change and the South African Water Sector, Water Research Commission, Pretoria, RSA, WRC Report TT 518/12. Chapter 9.1, 257-274.

[15] Mukheibir, P. (2007) Access to Water-The Impact of Climate Change in Small Municipalities. University of Cape Town, Cape Town.

[16] Schulze, R.E. (2011) Climate Proofing the South African Water Sector 2: An Initial Study on Practical Suggestions for Adaptation to Climate Change. In: Schulze, R.E., Ed., A 2011 Perspective on Climate Change and the South African Water Sector. Water Research Commission, Pretoria, RSA, WRC Report TT 518/12, Chapter 9.3, 311-366.

[17] WWAP (United Nations World Water Assessment Programme) (2015) The United Nations World Water Development Report 2015: Water for a Sustainable World. UNESCO, Paris.

[18] ASSAf (2012) Science, Water and Sanitation: Supporting Equitable and Sustainable Development in Southern Africa. Academy of Science of South Africa, Pretoria.

[19] DWS (2016) Annual Performance Plan for the Fiscal Years 2016/17 to 2018/19: Vote 36. Department of Water and Sanitation, Pretoria.

[20] World Water Assessment Programme (2009) The United Nations World Water Development Report 3: Water in a Changing World. Paris, UNESCO, and London, Earthscan. http://www.unesco.org/water/wwap/wwdr/wwdr3/

[21] ICOLD-ICID-IHA-IWRA (2012) Water Storage for Sustainable Development. World Declaration Approved on 5th June 2012 in Kyoto, by The International Commission On Large Dams (ICOLD), The International Commission on Irrigation and Drainage (ICID), The International Hydropower Association (IHA), and the International Water Resources Association (IWRA), Kyoto.

[22] DWA (2011) Infrastructure Indaba. Department of Water Affairs, Republic of South Africa, Pretoria.

[23] Eguavoen, I. and McCartney, M. (2013) Water Storage: A Contribution to Climate Change Adaptation in Africa. Scientific World, Rural 21-01/2013, 38-41. 
[24] DWS (2016) Water and Sanitation Sector Policy Position on Climate Change. Draft Document, Department of Water and Sanitation, Republic of South Africa, Pretoria.

[25] McCartney, M.P. and Smakhtin, V. (2010) Water Storage in an Era of Climate Change: Addressing the Challenge of Increasing Rainfall Variability. Blue Paper. Colombo, International Water Management Institute (IWMI), Sri Lanka, 14 p.

[26] Grey, D. and Sadoff, C.W. (2006) Water for Growth and Development. Thematic Documents of the IV World Water Forum, Comision Nacional del Agua, Mexico City.

[27] SIWI (2004) Making Water a Part of Economic Development: The Economic Benefits of Improved Water Management and Services. Stockholm International Water Institute (SIWI), Stockholm. 